\title{
Sea turtle consumption and black market trade in Baja California Sur, Mexico
}

\author{
Agnese Mancini, Volker Koch* \\ Depto. de Biología Marina, Universidad Autonóma de Baja California Sur, Carretera al Sur km 5.5, 23080 La Paz, \\ Baja California Sur, Mexico
}

\begin{abstract}
We examined sea turtle consumption and illegal trade in Baja California Sur (BCS) using data from (1) bimonthly surveys at beaches, fishing camps and dumpsites and (2) semi-structured interviews with fishermen. From March 2006 to February 2008, we found the carcasses of 1014 sea turtles; the meat of 461 of these turtles $(45.5 \%)$ had been consumed. The East Pacific green turtle Chelonia mydas was the most sought-after species ( $77 \%$ of total consumed turtles). Consumption is still the main cause of mortality for sea turtles and the greatest threat to them in BCS, affecting mostly juvenile-sized specimens. Sea turtle consumption occurred all year round with a lower number recorded from November to February and an increase thereafter. From 151 interviews we identified 3 areas where turtle meat is consumed but not sold, 4 areas with a local black market and 3 areas providing for a regional and/or international black market. Prices vary from $2-5 \mathrm{USD} \mathrm{kg}^{-1}$ (entire turtle sold on the beach) to $4-20 \mathrm{USD} \mathrm{kg}^{-1}$ (meat only). Consumption of sea turtle meat is partly related to cultural factors, as it is consumed more frequently during the Christian fasting period of Lent. While trade and consumption have decreased in recent years, there are still several places that supply sea turtle meat to local, regional, and sometimes even international markets. Authority involvement in sea turtle traffic and the lack of law enforcement need to be addressed to improve sea turtle conservation in the region. The use of both qualitative and quantitative data in the present study has helped to gain a better understanding of sea turtle consumption in BCS.
\end{abstract}

KEY WORDS: Sea turtle $\cdot$ Poaching $\cdot$ Illegal trade $\cdot$ Northwest Mexico $\cdot$ Mortality $\cdot$ Wild meat • Consumption Resale or republication not permitted without written consent of the publisher

\section{INTRODUCTION}

Hunting wildlife for human consumption is considered one of the major threats to biodiversity conservation (Milner-Gulland et al. 2003). Especially in the tropics, where wild meat is an important source of protein and income for many people (Bennett \& Robinson 2000), overhunting has led to the local and/or global extinction of many species (Bennett et al. 2002, Jerozolimski \& Peres 2003). In Mexico, the exploitation of sea turtles has been a traditional activity among coastal communities for centuries. Most indigenous tribes on the coast used to catch sea turtles for subsistence, and Seri Indians along the Sonoran coastline used the green turtle as their main source of animal protein (Dawson 1945, Caldwell 1963, Felger \& Moser 1985, Nabhan 2003, Delgado \& Nichols 2005).

In the mid-19th century, whalers extensively exploited sea turtles as a supply of fresh meat (Scammon 1970, O'Donnell 1974, Nichols 2003). By the end of the 19th century, green turtle soup had become particularly popular in Great Britain, and new markets started to develop in Europe and Asia (Nietschmann 1995, Fleming 2001). The rising market demand led to an increase in sea turtle exploitation throughout the first half of the 20th century, which reached its peak between the 1950s and the early 1970s (Caldwell 1963, O'Donnell 1974, Cliffton et al. 1995) when more than $50 \%$ of the world's sea turtle catch occurred in Mexico (Marquez et al. 1982, Marquez 1990, FAO Fishery 
Department 2000). Most of the harvest for consumption was focused on the East Pacific green turtle Chelonia mydas, while olive ridley Lepidochelys olivacea and hawksbill Eretmochelys imbricata turtles were mainly exploited for their leather and shell, respectively. Loggerhead turtles were caught accidentally and only rarely consumed. Additionally, intensive egg harvesting affected all species alike. As a result, all sea turtle populations in Mexico collapsed, forcing the Mexican government to declare a total ban on sea turtle fisheries and trade of derived products in 1990 (DOF 1990). Despite the ban, sea turtle meat is still considered a delicacy in Baja California Sur (BCS) and is consumed on festive occasions (Gardner \& Nichols 2001, Delgado \& Nichols 2005, Koch et al. 2006). Additionally, sea turtle blood and oil are believed to cure anemia and asthma, respectively (Garcia-Martínez \& Nichols 2000, Delgado \& Nichols 2005).

Although there are severe penalties for the capture and traffic of sea turtle products, including up to 9 years in jail and a 15000 USD fine (Anonymous 1996), compliance and law enforcement are major problems. Of more than 39 infractions reported by PROFEPA, the federal agency for the protection of the environment (Peralta Gallegos, federal delegate of PROFEPA in BCS, pers. comm.), only 10 people were sentenced between 1990 and 2008 (Espinosa Pastrán, Attorney General's Office, pers. comm.). Furthermore, penalties are usually only around $10 \%$ of the maximum laid down by the law (Espinosa Pastrán pers. comm.). Recent studies demonstrate that mortality rates due to illegal hunting remain very high in BCS. Gardner \& Nichols (2001) reported that $78 \%$ of 514 carcasses collected from 3 coastal communities in 1999 showed evidence of consumption. Koch et al. (2006) found that consumption accounted for more than $75 \%$ of total mortality from 2000 to 2003 in Bahia Magdalena, a 28 coastal lagoon covering approximately $1200 \mathrm{~km}^{2}$. Nevertheless, the illegal nature of sea turtle consumption and trade impedes the collection of reliable records of consumed meat, a situation similar to that for terrestrial wild meat (Milner-Gulland et al. 2003, Hilaluddin et al. 2005). An overview of the socio-economic context and a better understanding of the extent of sea turtle consumption are necessary to improve sea turtle conservation (Milner-Gulland et al. 2003, Delgado \& Nichols 2005). Thus, our objective was to quantify the minimum sea turtle consumption rate in BCS and describe the illegal trade. We used 2 approaches: (1) we conducted bimonthly surveys at beaches and dumpsites to assess minimum numbers of sea turtles that died over time, their species composition and size frequencies, and (2) we conducted semi-structured interviews with fishermen to gather qualitative and quantitative information about illegal trade and consumption.

\section{MATERIALS AND METHODS}

Study area. BCS is approx. $900 \mathrm{~km}$ long and is located between $28^{\circ} 00^{\prime} \mathrm{N}$ and $22^{\circ} 52^{\prime} \mathrm{N}$, and between $109^{\circ} 25^{\prime} \mathrm{W}$ and $115^{\circ} 05^{\prime} \mathrm{W}$ (Fig. 1). It has the longest coastline of all Mexican states (approximately $2222 \mathrm{~km}$ ) and includes many islands of volcanic origin, mostly located in the Gulf of California (Thomson et al. 1979). Lagoons, bays, rocky shorelines and sandy beaches characterize the coastline, with 3 major lagoon systems located on the Pacific side: Ojo de Liebre lagoon, San Ignacio Lagoon and Bahia Magdalena. The lagoons harbor extensive seagrass and algae beds, with mangrove forests in San Ignacio lagoon and Bahía Magdalena (Zaytsev et al. 2003).

The state of BCS has 512170 inhabitants living mainly in the southern part of the peninsula in La Paz and Los Cabos. The rest of the population is scattered over more than 4000 small towns and villages (INEGI 2005). Historically, fishing was one of the main economic activities, with the squid and sardine fisheries being the most important in terms of production (CONAPESCA 2003). In terms of employed people and number of boats, the artisanal fishing fleet is more important than the industrial fishery, and consists of

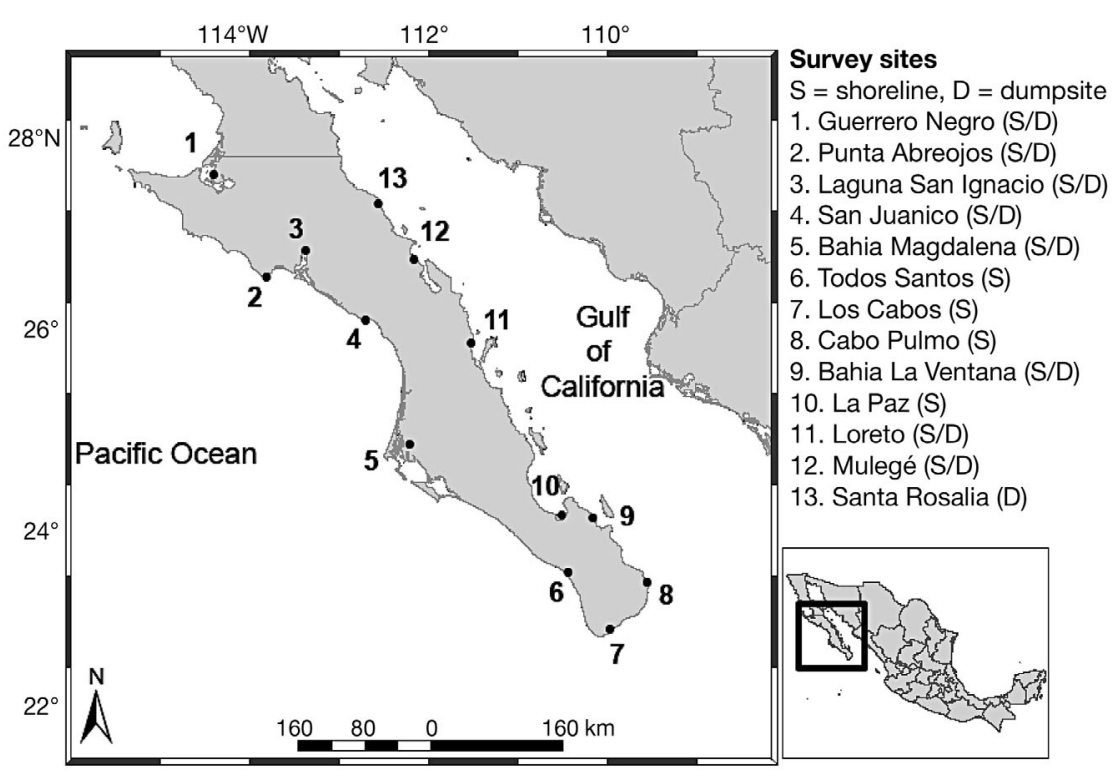

Fig. 1. Study area in Baja California Sur (BCS), Mexico 
approximately 3630 'pangas', small fibreglass skiffs (6 to $8 \mathrm{~m}$ long) with outboard motors (65 to $200 \mathrm{hp}$ ). These vessels are operated by 2 to 4 fishermen (CONAPESCA 2003). Although artisanal fisheries only represent $8.3 \%$ of the total income of $\mathrm{BCS}$, they employ approximately $15 \%$ of the working population directly, with many more people dependent on them (INEGI 2005).

Field sampling. Mortality censuses were carried out from March 2006 to February 2008 (24 mo) at 13 index sites in the state (Fig. 1). At each site, 15 to $30 \mathrm{~km}$ of beach and the villages and dumpsites were searched bimonthly. Based on the sampling protocol described by Koch et al. (2006), dead turtles were identified, measured (curved carapace length CCL and width CCW, to the nearest $\mathrm{mm}$ ) and photographed. Geographical position of each carcass was determined using a handheld GPS. All carcasses were marked with spray paint and/or cable binders, to avoid double counting of specimens on later censuses. Based on external evidence, we determined if the mortality was due to: (1) consumption: only the carapace was found; this was often burned and sometimes harpoon holes could be seen, or (2) other mortality: the animal was more or less intact, perhaps with evidence of fibropapilloma tumors, shark bites, traces of nets or wounds caused by other fishing gear, or boat strike.

The total count of dead turtles for each species provided a minimum mortality estimate. The percentage of 'consumption mortality' was calculated for each species based on the criteria explained above. We used mean nesting size of female turtles as an estimate for size at maturity (Alvarado-Diaz \& Figueroa 1990, Marquez 1990, IUCN 2007) to determine the percentage of adult and juvenile-sized turtles (Limpus 1992, Limpus \& Limpus 2003; Koch et al. 2006). The spatial mortality distribution was mapped using ArcView 9.1.

A total of 185 semi-structured interviews were conducted with fishermen to collect information on illegal trade of sea turtles at 13 coastal areas (Appendix 1). At each site a minimum of $5 \%$ of the fishermen were interviewed - up to a maximum of 20 people in larger communities (Table 1). The overall aim of the interviews was to gain knowledge about fishermen's perception of local sea turtle abundance, consumption, and trade. Participants were chosen randomly from each community and interviewed separately, as group interviews usually result in interviewees hiding private information and following the group's opinion (Janis 1972). Due to the clandestine nature of sea turtle hunting and consumption, there was a risk that interviewees might attempt to bias the information in order to hide illegal activities (Sheil \& Wunder 2002). To reduce this possible bias, another local person was present at almost all the interviews to establish a feeling of trust between the in-
Table 1. Estimated number of artisanal fishermen (SAGARPA 2007) and total number of interviews carried out at each monitoring site. See Fig. 1 for site locations

\begin{tabular}{|lcc|}
\hline Site & $\begin{array}{c}\text { Estimated no. } \\
\text { of fishermen } \\
\text { (SAGARPA 2007) }\end{array}$ & $\begin{array}{c}\text { No. of interviews } \\
\text { (\% of fishermen) }\end{array}$ \\
\hline Guerrero Negro & 512 & $20(4)$ \\
Punta Abreojos & 218 & $20(9)$ \\
Laguna San Ignacio & 176 & $20(11)$ \\
Bahía Magdalena & 1252 & $17(1)$ \\
Todos Santos & 100 & $15(15)$ \\
Los Cabos & 96 & $7(7)$ \\
Cabo Pulmo & 66 & $8(12)$ \\
Bahia La Ventana & 154 & $8(5)$ \\
La Paz & 112 & $8(7)$ \\
Loreto & 136 & $10(7)$ \\
Mulegé & 278 & $17(6)$ \\
Santa Rosalía & 430 & $20(5)$ \\
Total & 3580 & $185(5)$ \\
\hline
\end{tabular}

terviewee and the interviewer. Before starting each interview, we explained the purpose of our study and guaranteed the interviewee strict confidentiality and anonymity. We used semi-structured interviews, which were conducted as informal but guided talks, to make the interviewee feel more comfortable. Each interview consisted of 2 parts, gathering information on (1) sea turtle species present, feeding areas and seasonal variations of abundance; and (2) illegal fishery, presence/ absence of poachers, presence/absence and extent of a black market, traffic routes and prices. The first part of the interview aimed to obtain an estimate of resource availability throughout the year. The second part aimed to gain a description of the extent and workings of the black market at each site.

Based on the level of exploitation of sea turtles, we classified each community into one of 3 categories, based on presence/absence of poachers, extent of sea turtle trade and main destinations of sea turtle meat: (1) consumption at a family level, no black market trade detected, no poachers present; (2) local market, sea turtles were sold within the community and poachers were present; (3) regional and/or international market, where sea turtles were sold throughout and often outside the state, and poachers were present.

We asked several questions that should have yielded the same answers to assess the consistency of the information compiled (see Appendix 1, Questions 7 and 14 and Questions 9 and 11, for examples). When the interviewee was reluctant to answer questions or was obviously giving false information, the interview was discarded and not included in the final analysis. We also collected some qualitative and anecdotal data, which was tested through further inquiry, as suggested by Tambiah (1999). 


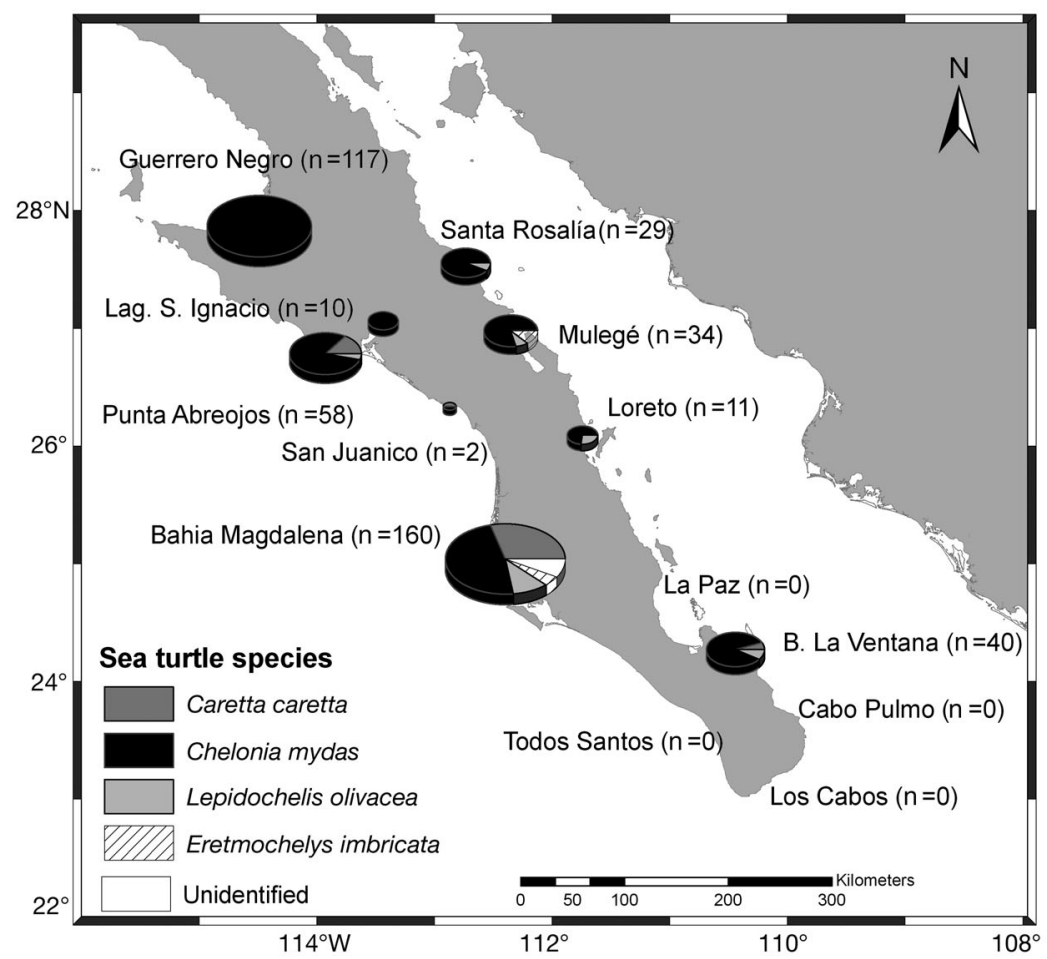

Fig. 2. Distribution of sea turtle carcasses found in villages and dumpsites during the survey (March 2006 to Feb 2008). All carcasses showed evidence of consumption. Circle size is proportional to the total number of carcasses encountered at each site. For full site names see Fig. 1

\section{RESULTS}

We found 1014 dead turtles after 24 mo of mortality census (March 2006 to February 2008), representing an average annual mortality rate of 507 sea turtles. Of these, 461 (45.5\% of total recorded mortality) had been consumed, representing a minimum average annual consumption mortality of 230.5 sea turtles. $60 \%$ of all consumed turtles were found in 2 areas: Guerrero Negro and Bahia Magdalena (Fig. 2). The East Pacific green turtle was the most sought-after species for consumption $(77.0 \%)$, followed by the loggerhead Caretta caretta turtle $(13.5 \%)$. Consumption of olive ridley and hawksbill turtles was more sporadic; these species comprised 7.1 and $2.4 \%$ of the recorded consumption mortality, respectively. CCLs for consumed East Pacific green turtles ranged from 38.5 to $101.0 \mathrm{~cm}(\mathrm{n}=335$; mean $\pm \mathrm{SD}$ : $62.0 \pm 12.5 \mathrm{~cm})$. CCLs for consumed loggerhead turtles ranged from 51.5 to $88 \mathrm{~cm}$ CCL $(\mathrm{n}=60$; mean \pm SD: $70.3 \pm$ $9.28 \mathrm{~cm})$. Almost all the consumed East Pacific green and loggerhead turtles were juvenile-sized (90 and 99\% respec-

\section{a Chelonia mydas}

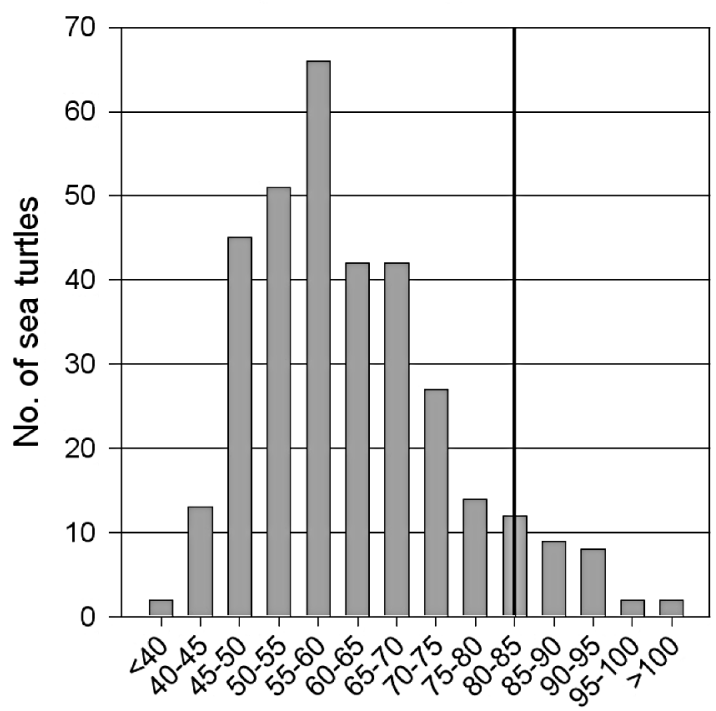

b Caretta caretta

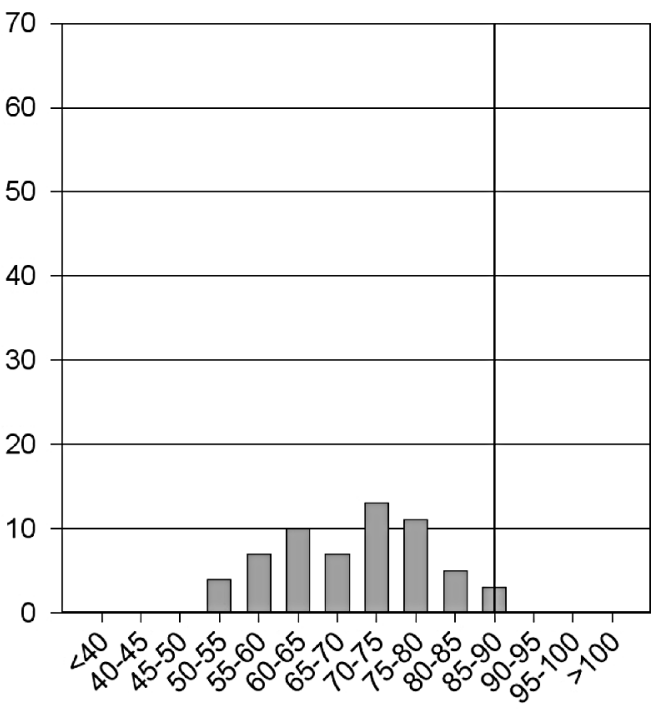

Size classes $(\mathrm{cm})$

Fig. 3. Chelonia mydas and Caretta caretta. Size frequency distribution of the curved carapace length (CCL, in $\mathrm{cm})$ of East Pacific green and loggerhead turtles, (a) Chelonia mydas and (b) Caretta caretta, consumed in BCS between March 2006 and February 2008. The black line indicates the average CCL for nesting females 
tively) (Fig. 3). Sea turtle consumption occurred all year round with lower numbers recorded from November to February, and a sharp increase thereafter (Fig. 4).

Of the 185 interviews, only 151 were analyzed, as in 20 cases the fishermen refused to answer our questions (representing a response rate of $89 \%$ ), and in 14 cases the interviewees gave false information (e.g. denying the presence of sea turtles in known feeding areas, or denying that sea turtles are, or have been, consumed). The interviewees reported that East Pacific green turtles were abundant all year round especially in lagoons and bays, both on the Pacific and Gulf side. Loggerhead turtles were reported from the north Pacific communities as being abundant during summer but not close to the coast.

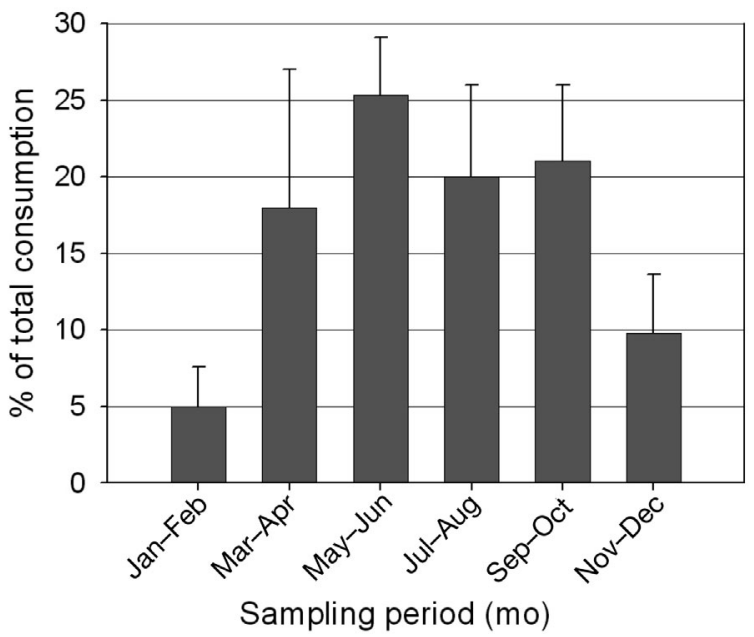

Fig. 4. Consumption frequency of sea turtle meat plotted bimonthly (data from March 2006 to February 2008) as average percentage of total sea turtle meat consumption.

Bars represent standard error
The olive ridley turtle was reported to be abundant all year round but only on the southern part of the Pacific coast and in the Gulf of California. Both hawksbill and leatherback turtles were reported as very rare and/or unknown. This is consistent with our field surveys (we found only 11 hawksbill turtles and no leatherbacks).

The main results from the interviews are reported in Fig. 5. Punta Abreojos-La Bocana, San Juanico and Loreto were categorized as communities where consumption of turtle meat is a common practice in families, and was reported by $46 \%$ of the interviewees in these communities. In Santa Rosalia, Mulegé, La Ventana and San Ignacio, trade was considered local, with turtles being sold mainly within the community, and was reported by $74 \%$ of the interviewees from these communities. Finally, we identified 3 centres for regional sea turtle trade: Guerrero Negro, from where meat or live turtles are taken to northern Baja California and even to some US cities such as San Diego and Los Angeles (reported in $89 \%$ of the interviews conducted in this community); Todos Santos, from where sea turtle meat is usually transported to La Paz or Los Cabos (reported by only $0.14 \%$ of the interviews conducted in this community, but in $20 \%$ of interviews from all other communities); and Bahia Magdalena, from where live sea turtles or meat is transported first to Ciudad Constitución and then to northern Baja California (Ensenada, Tijuana, Mexicali) or south to La Paz (reported in $33 \%$ of the interviews conducted in the area, and in $40 \%$ of interviews from other communities) (Fig. 6). Fishermen from communities on the Gulf coast also reported poachers from the states of Sonora and Sinaloa (on the other side of the Gulf) catching an unknown number of turtles to sell in their own communities (23\% of total interviews) (Fig. 6).

Table 2. Prices for sea turtles and their meat compared with most common sources of animal protein. The price for an entire turtle usually refers to the amount paid by customers on the beach. Meat is sold both directly on the beach and in villages; cooked meat is usually sold in small shops. Beef, pork and chicken meat prices are for all sites and are based on frequent prices as reported by PROFECO (2008); price ranges in each case reflect different prices for the varios types of meat. See Fig. 1 for site locations

\begin{tabular}{|c|c|c|c|c|c|c|}
\hline \multirow[t]{2}{*}{ Area } & \multirow[b]{2}{*}{ Entire turtle } & \multirow[b]{2}{*}{ Meat } & \multicolumn{2}{|c|}{ Prices in USD kg-1 (average) } & \multirow[b]{2}{*}{ Pork } & \multirow[b]{2}{*}{ Chicken } \\
\hline & & & Cooked meat & Beef & & \\
\hline Guerrero Negro & $2-4.5(3.3)$ & $5-12(8.5)$ & & $3.9-16.8$ & $1.8-7.5$ & $2.4-5.2$ \\
\hline Punta Abreojos ${ }^{\mathrm{a}}$ & & $10-12(11)$ & & & & \\
\hline Laguna San Ignacio & 4.5 & $10-12(11)$ & & & & \\
\hline Bahía Magdalena & 4.5 & $10-15(12.5)$ & & & & \\
\hline Todos Santos & & $4-5(4.5)$ & & & & \\
\hline Los Cabos $^{b}$ & & $12-20(16)$ & & & & \\
\hline $\mathrm{La} \mathrm{Paz}^{\mathrm{c}}$ & & 12 & $20-30(25)$ & & & \\
\hline Santa Rosalía & 4 & & & & & \\
\hline
\end{tabular}




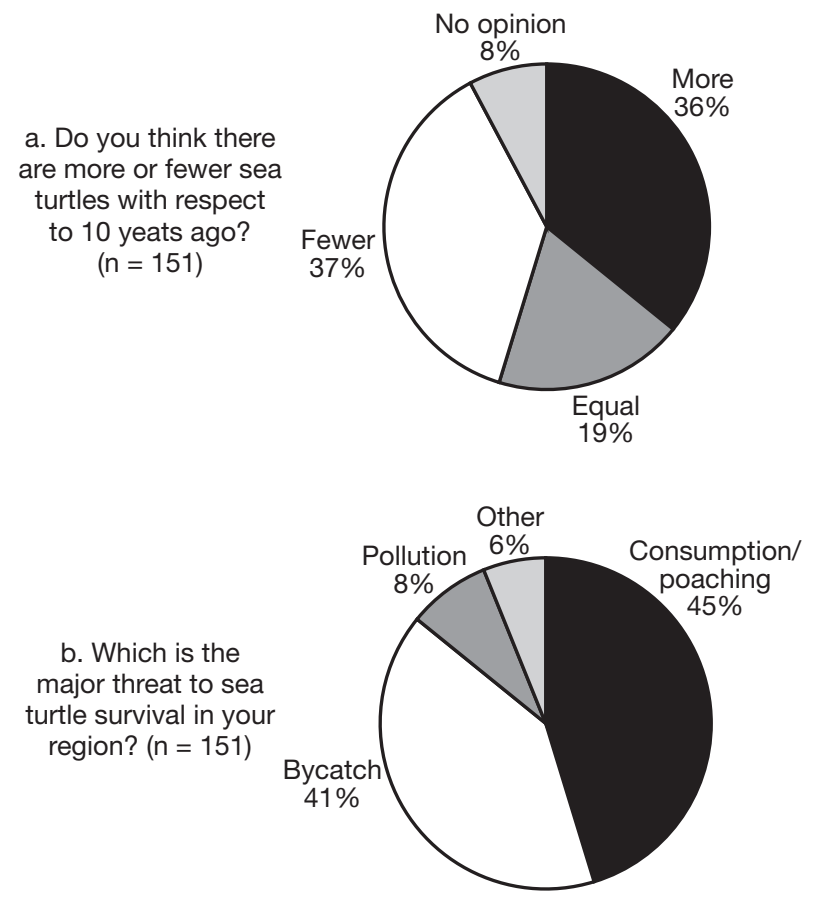

c. For those who answered consumption and/or poaching, do you think that this threat is now less or more intense with respect to 10 years ago? $(n=68)$

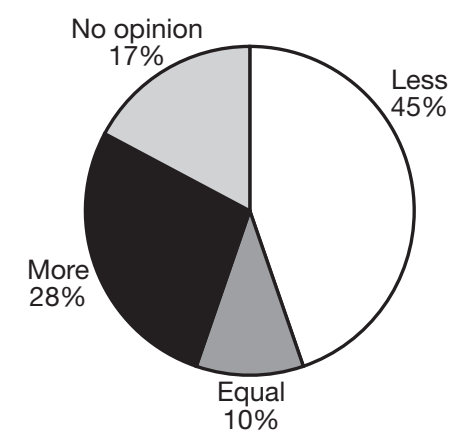

Only $31 \%$ of the interviewees knew the market price for live sea turtles and/or turtle meat. An entire turtle of any species sold directly on the beach is valued at around 2 to $5 \mathrm{USD} \mathrm{kg}^{-1}$ (mean $=4.1 \mathrm{USD} \mathrm{kg}^{-1}, \mathrm{n}=44$ ). Meat is more expensive and may cost 4 to $20 \mathrm{USD} \mathrm{kg}^{-1}$ (mean $=10.8 \mathrm{USD} \mathrm{kg}^{-1}, \mathrm{n}=20$ ) (Table 2). In cities like Los Cabos and La Paz, usually only sea turtle meat is sold, and the prices are much higher than in smaller coastal communities. $90 \%$ of the interviewees stated that government authorities may be involved in sea turtle traffic, receiving bribes from people who are involved in the black market trade, and named teachers, policemen, and government authorities as regular customers/consumers.

\section{DISCUSSION}

\section{Field surveys}

Our dumpsite surveys underestimate actual consumption rates, as (1) mortality censuses were carried

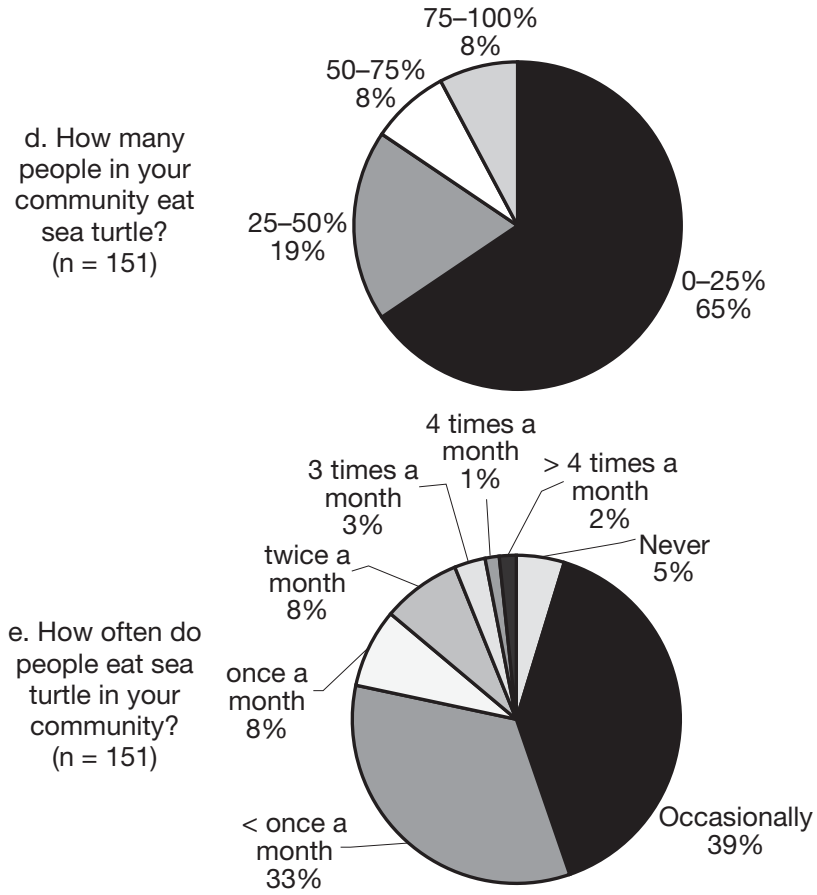

Fig. 5. Main results obtained from interviews with fishermen on their perception of sea turtle-related issues for all communities combined

out only every 2 mo and carcasses were buried under trash between surveys, (2) the trash is burned to manage overflowing dumpsites, thus destroying much of the evidence, (3) the census included only 20 coastal communities (less than $15 \%$ of the coastal communities and fishing camps in BCS), and (4) poachers have become much more cautious, usually killing turtles at sea, taking only the meat and throwing the carcasses into the sea, or hiding them in the desert (Koch et al. 2006).

However, our mortality data should be a reliable index of which species and size ranges are most affected by consumption, as well as of the spatial and temporal mortality distribution. Consumption is still the main cause of human-induced sea turtle mortality in the region, confirming previous studies (Gardner \& Nichols 2001, Koch et al. 2006, Peckham \& Nichols 2006) and occurs throughout the state. Sea turtles are caught directly for consumption or are a welcome bycatch (Koch et al. 2006). However, it was impossible from dumpsite surveys to distinguish between these 2 


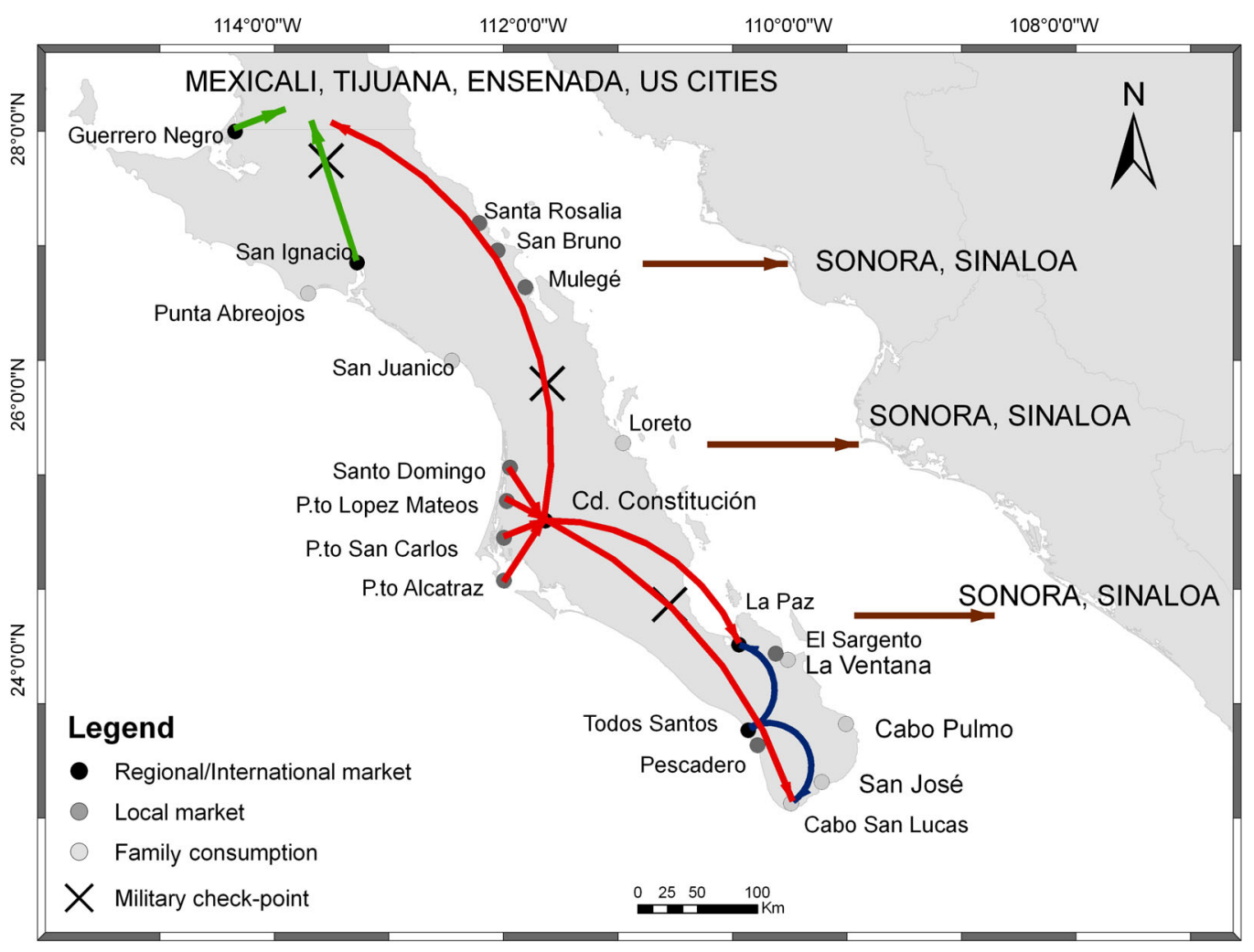

Fig. 6. Traffic routes and black market for sea turtle in Baja California Sur. Paved highways are normally used to transport the meat but sometimes dirt roads are taken. Arrows indicate various sea turtle traffic routes

sources; thus the consumption figure presented here includes both deliberately and accidentally caught turtles.

The East Pacific green turtle is eaten most often as it is considered the tastiest species (Garcia-Martínez \& Nichols 2000, Nichols 2003). However, dumpsite surveys suggest that in some locations all species are consumed, depending on their availability throughout the year (Koch et al. 2006). For example, loggerhead turtles are consumed within certain communities in the area of Bahia Magdalena (specifically in Santo Domingo), where fishermen usually work in an important loggerhead feeding area (Peckham \& Nichols 2006, Peckham et al. 2007). The olive ridley turtle is more regularly consumed in the south of the peninsula (from Todos Santos to La Paz), a nesting and feeding area for adult turtles (Marquez 1990, IUCN 2007). The consumption of hawksbill turtles is sporadic, due to the rarity of the species in BCS (Marquez 1990, Nichols 2003).

Most of the dead turtles were juvenile or subadult in size (Koch et al. 2006, 2007). While Crouse et al. (1987), Crowder et al. (1994) and Crouse (1999) consider that the survival of juveniles and subadults is critical for the recovery of sea turtle populations,
Chaloupka (2002) suggests that the harvest of adults could have a greater impact on sea turtle survival. Nevertheless, all these authors agree that harvesting even small numbers of sea turtles of any size can increase the risk of population decline. This concerns the East Pacific green turtle in particular because natural mortality of juveniles in BCS waters is known to be very low at this life stage when this species spends most of its time inside bays and lagoons where there are very few natural predators (Koch et al. 2007).

\section{Sea turtle consumption}

The following shortcomings of the interview process must be borne in mind when considering the results: although the interviewee has good knowledge of the local situation, he may not have a broad view of the problem, and/or may not recall the past accurately (Bradburn et al. 1987). Nevertheless, this approach is very useful to describe the nature and extent of a problem (Jones et al. 2008). In the past, sea turtle meat was considered an affordable and abundant source of animal protein; nowadays, its economic and nutritional significance in BCS has changed due to the increased 
availability of a variety of animal protein (Delgado \& Nichols 2005). Nevertheless, demand for sea turtle meat persists (Delgado \& Nichols 2005), highlighting the fact that its consumption is largely related to traditional values and cultural factors. This is particularly evident when analyzing the consumption of sea turtle meat throughout the year: while this occurs all year round, there is a marked increase during Lent (usually between March and April) and thereafter, when it is served as a substitute for red meat (Safina et al. 2005, Garcia-Martínez \& Nichols 2000).

In the literature, wild meat trade and consumption are usually related to the need for animal protein in the diet, and to the income the trade generates for the poacher (Millner-Gulland et al. 2003). However, the motivations behind sea turtle consumption and black market trade appear to be more complex. GarciaMartínez \& Nichols (2000) stated that demand for turtle meat is inversely related to family income. However, as sea turtle meat has gained a new value as an emblem of wealth and power (Delgado \& Nichols 2005), this pattern has changed. Our study suggests that a significant proportion of the demand for turtle meat comes from well-educated persons with a secure income. This conclusion is supported by the economic theory of 'income and consumption', which suggests that as income rises, consumption of a commodity will also rise if this commodity is considered a necessity or of better quality (Kuznets 1955, Hilaluddin et al. 2005). Sea turtle meat is often considered tastier than fish, chicken or shellfish (Garcia-Martínez \& Nichols 2000), and prices are similar to those of other meat types in coastal communities (Table 2). However, in larger cities (e.g. Los Cabos and La Paz), prices increase as the distance from the point of capture increases and sea turtle meat can be considered a luxury item. A similar situation has been reported for wild meat consumption in Gabon (Abernethy \& Ntsame Effa 2002).

\section{Black market and trade}

In the Caribbean, sea turtle consumption is reported to be occasional and decreasing (Fleming 2001), and the same pattern can be found in many communities in BCS. Nevertheless, we found that there are still local/regional markets that supply sea turtle meat and derived products. Main traffic routes originate in communities where the legal sea turtle fishery was important before the ban in 1990 (Turrubiates Moran, INAPESCA, pers. comm.). Between 1950 and 1990, sea turtles were exploited by 3 cooperatives in Todos Santos, Guerrero Negro and Bahia Magdalena, and packed for trade (Olguín-Mena 1990). From these localities, sea turtle meat is still transported as far as
Mexicali, Tijuana, Ensenada and even to some US cities such as San Diego and Los Angeles, where many Latinos live. While regional traffic is usually organized in a network (fisher-middleman-final customer) (Nichols 2003, present study), sea turtle meat is supplied locally by fishermen from the community. This activity represents an extra income, as a live sea turtle can be sold for around 120 USD (taking an average price on the beach of $4 \mathrm{USD} \mathrm{kg}{ }^{-1}$ and a mean weight of $30 \mathrm{~kg}$ turtle $^{-1}$, i.e. the average weight per turtle reported by fishermen during the interviews).

In $90 \%$ of the interviews, we were told that authorities are involved in sea turtle traffic. What emerges is that corruption and/or collaboration occurs at different levels, which usually encourages illegal trade (Keane et al. 2008). This, together with the lack of law enforcement is among the key-points to be addressed to reduce trade of endangered species and ensure their long-term survival (Milner-Gulland et al. 2003). Even if our data only represent minimum consumption rates, we believe that our approach, using both qualitative and quantitative data, gives a good overview of a situation that is hard to assess, and that our results are important for improving sea turtle conservation in the region.

Acknowledgements. We thank Secretaria de Medio Ambiente y Recursos Naturales (SEMARNAT) for providing the permits under which this study was conducted. This project was funded by Consejo Nacional de Ciencias y Technología (CONACyT) grant SEMARNAT-2004-C01-277. We also thank all the people who allowed us to interview them, the members of the Grupo Tortuguero, and everybody who helped to conduct censuses of smelly carcasses. Special thanks go to Victor, Marisel and Vladimir de la Toba, and Javier Villavicencio for their invaluable help. Our thanks also go to Helene Marsh and 3 anonymous reviewers for their comments and corrections, which helped to improve the manuscript greatly. A.M. was supported by Rufford Small Grants for Conservation and Society for Conservation GIS.

\section{LITERATURE CITED}

Abernethy K, Ntsame Effa E (2002) Gestion de la filière viande de brousse. Rapport pour la Direction de la Faune et Chasse, Libreville

Alvarado-Diaz J, Figueroa A (1990) The ecological recovery of sea turtles of Michoacan, Mexico. Special attention: the black turtle, Chelonia agassizii. US Fish and Wildlife Service, Albuquerque, NM

Anonymous (1996) Título vigésimo quinto. Delitos contra el ambiente y la gestión ambiental. Mexico City

Bennett EL, Robinson JG (2000) Hunting of wildlife in tropical forests: Iimplications for biodiversity and forest peoples. Environment Department Papers, Biodiversity Series no. 76, World Bank, Washington, DC

Bennett EL, Eves H, Robinson J, Wilkie D (2002) Why is eating bushmeat a biodiversity crisis? Conserv Pract 3:28-29

Bradburn NM, Rips LJ, Shevell SK (1987) Answering autobio- 
graphical questions - the impact of memory and inference on surveys. Science 236:157-161

Caldwell DK (1963) The sea turtle fishery of Baja California, Mexico. Calif Fish Game 49:140-151

> Chaloupka M (2002) Stochastic simulation modelling of southern Great Barrier Reef green turtle population dynamics. Ecol Model 148:79-109

Cliffton K, Cornejo DO, Felger RS (1995) Sea turtles of the Pacific coast of Mexico. In: Bjorndal KA (ed) Biology and conservation of sea turtles. Smithsonian Institute Press, Washington, DC

Comisión Nacional de Acuacultura y Pesca (CONAPESCA) (2003) Anuario estadistico de Acuacultura y Pesca 2003. CONAPESCA, Mazatlán

Crouse DT (1999) The consequences of delayed maturity in a human-dominated world. Life in the slow lane: ecology and conservation of long-lived marine animals. Am Fish Soc Symp 23:195-202

Crouse DT, Crowder LB, Caswell H (1987) A staged-based population model for loggerhead sea turtles and implication for conservation. Ecology 68:1412-1423

Crowder LB, Crouse DT, Heppell SS, Martin TH (1994) Predicting the impact of turtle excluder devices on loggerhead sea turtle populations. Ecol Appl 4:437-445

Dawson D (1945) The savage Seris of Sonora I. Sci Mon 60(3):193-202

Delgado S, Nichols WJ (2005) Saving sea turtles from the ground up: awakening sea turtle conservation in northwestern Mexico. Marit Stud 4(1):89-104

Diario Oficial de la Federación Mexico (1990) Acuerdo que establece veda para todas las especies y subspecies de tortugas marinas en aguas de jurisdicción nacional de los litorales del Oceano Pacifico, Golfo de Mexico y Mar Caraibe. Diario official de la Federación, Mexico, May 31, 1990, p 21-22

FAO (Food and Agriculture Organization) Fishery Department, Fishery Information, Data and Statistics Unit (2000) FISHSTAT Plus: universal software for fishery statistical time series. Version 3.2

Felger RS, Moser MB (1985) People of the desert and sea. University of Arizona Press, Tucson, AZ

Fleming EH (2001) Swimming against the tide: recent surveys of exploitation, trade, and management of marine turtles in the northern Caribbean. TRAFFIC North America, Washington, DC

Garcia-Martínez S, Nichols WJ (2000) Sea turtles of Bahía Magdalena, BCS, Mexico: demand and supply of an endangered species. 10th Conf Int Inst Fish Econ Trade, July 2000, Oregon State University, Corvallis, OR

Gardner SC, Nichols WJ (2001) Assessment of sea turtle mortality rates in the Bahia Magdalena region, BCS, Mexico. Chelonian Conserv Biol 4:197-199

Hilaluddin RK, Ghose D (2005) Conservation implications of animal biomass extractions in Northeast India. Animal Biodiv Cons 28:169-179

INEGI (2005) Anuario estadistico del estado de Baja California Sur. Available at: www.inegi.org.mx/inegi/default. aspx? $\mathrm{s}=\mathrm{est} \& \mathrm{C}=10382 \& \mathrm{e}=\& \mathrm{i}=<$

IUCN (2007) IUCN Red List of Threatened Species. Retrieved May 01, 2007. www.iucnredlist.org/ (accessed on 1 May 2007)

Janis IL (1972) Victims of groupthink. Houghton-Mifflin, Boston, MA

> Jerozolimski A, Peres CA (2003) Bringing home the biggest bacon: a cross-site analysis of the structure of hunter-kill profiles in neotropical forests. Biol Conserv 111:415-425

Jones JPG, Andriamarovololona MM, Hockley N, Gibbons
JM, Milner-Gulland EJ (2008) Testing the use of interviews as a tool for monitoring trends in the harvesting of wild species. J Appl Ecol 45:1205-1212

> Keane A, Jones JPG, Edwards-Jones G, Milner-Gulland EJ (2008) The sleeping policeman: understanding issues of enforcement and compliance in conservation. Anim Conserv 11:75-82

Koch V, Nichols WJ, Peckham H, de la Toba V (2006) Estimates of sea turtle mortality from poaching and bycatch in Bahía Magdalena, Baja California Sur, Mexico. Biol Conserv 128:327-334

Koch V, Brook LB, Nichols WJ (2007) Population ecology of the green/black turtle (Chelonia mydas) in Bahía Magdalena, Mexico. Mar Biol 153:35-46

Kuznets S (1955) Economic growth and income inequity. Am Econ Rev 445:1-28

Limpus CJ (1992) The hawksbill turtle, Eretmochelys imbricata, in Queensland: population structure within a southern Great Barrier Reef feeding ground. Wildl Res 19:489-506

Limpus CJ, Limpus DJ (2003) Biology of the loggerhead turtle in western south Pacific foraging areas. In: Bolten $A B$, Witherington BE (eds) Loggerhead sea turtles. Smithsonian Institution Press, Washington, DC, p 93-113

Marquez R (1990) Sea turtles of the world. An annotated and illustrated catalogue of sea turtle species known to date. FAO Species Catalogue, FAO Fish Synop 11(125)

Marquez R, Peñaflores CS, Villanueva AO, Diaz JF (1982) A model for diagnosis of populations of olive ridleys and green turtles of west Pacific tropical coasts. In: Bjorndal KA (ed) Biology and conservation of sea turtles. Smithsonian Institution Press, Washington, DC, p 153-158

Milner-Gulland EJ, Bennett EL, SAMWM Group (2003) Wild meat: the bigger picture. Trends Ecol Evol 18:351-357

Nabhan GP (2003) Singing the turtles to sea: the Comcáac (Seri) art and science of reptiles. University of California Press, Berkeley, CA

Nichols WJ (2003) Biology and conservation of the sea turtles of the Baja California peninsula, Mexico. PhD dissertation, University of Arizona, Tucson, AZ

Nietschmann B (1995) The cultural context of sea turtle subsistence hunting in the Caribbean and problems caused by commercial exploitation. In: Bjorndal KA (ed) Biology and conservation of sea turtles. Smithsonian Institution Press, Washington, DC, p 439-445

O'Donnell J (1974) Green turtle fishery in Baja California waters: history and prospect. Master's thesis, California State University, Northridge, CA

Olguín-Mena M (1990) Las tortugas marinas en la costa oriental de Baja California y costa Occidental de Baja California Sur, México. MS thesis, UABCS, La Paz

Peckham H, Nichols WJ (2006) An integrated approach to reducing mortality of North Pacific loggerhead turtles in Baja California Sur, Mexico. In: Kinan I (ed). Proc 2nd Western Pacific Sea Turtle Cooperative Research and Management Workshop. Vol II, North Pacific Loggerhead Sea Turtles. March 2-3, 2005, Honolulu, HI. Western Pacific Regional Fishery Management Council, Honolulu, $\mathrm{HI}$

Peckham SH, Maldonado Diaz D, Walli A, Ruiz G, Crowder LB, Nichols WJ (2007) Small-scale fisheries bycatch jeopardizes endangered Pacific loggerhead turtles. PLoS One 2:e1041

Procuraduría Federal del Consumidor (PROFECO) (2008) Quien es quien en los precios. Available online at: http:// www.profeco.gob.mx/precios/df/carnes.asp (accessed April 2008) 
Safina C, Gilman E, Nichols WJ (2005) Twine and the ancient mariners - albatross, sea turtles and fishing gears encounters. In: Wildlife Conservation Society (ed) State of the wild 2006: a global portrait of wildlife, wildlands, and oceans. Island Press, Washington, DC

Secretaria de Agricultura, Ganadería, Desarrollo rural, Pesca y Alimentación (SAGARPA) (2007) Anuario estadistico de pesca: Permisionarios de embarcaciones menores y mayores. CONAPESCA, Mazatlán

Scammon CM (1970) Journal aboard the bark Ocean Bird on a whaling voyage to Scammon's Lagon, winter of 1858-1859. Henderson DA (ed) Dawson's Book Shop, Los Angeles, CA
Sheil D, Wunder S (2002) The value of tropical forest to local communities: complications, caveats, and cautions. Conserv Ecol 6:9

Tambiah C (1999) Interviews and market surveys. In: Eckert KL, Bjorndal KA, Abreu-Grobois FA, Donnelly M (eds) Research and management techniques for the conservation of sea turtles. IUCN/SSC Marine Turtle Specialist Group Publ. No. 4, IUCN, Gland

Thomson DA, Findley L, Kerstich A (1979) Common reef fishes from the sea of Cortez. John Wiley \& Sons, New York

Zaytsev O, Cervantes-Duarte R, Montante O, Gallegos-Garcia A (2003) Coastal upwelling activity on the Pacific shelf of the Baja California peninsula. J Oceanogr 59:489-502

Appendix 1. Questions asked during semi-structured interviews with fishermen

\author{
Part I: Sea turtle biology \\ 1. Have you seen sea turtles in this area? \\ 2. Can you say which species are the most common in this area? \\ 3. In which season/month are sea turtles most abundant? \\ 4. Is there a specific area where sea turtles feed/aggregate? \\ 5. Do you think that there are more or fewer sea turtles with respect to 10 years \\ ago? \\ $\square$ More $\square$ Equal $\square$ Fewer $\square$ No opinion
}

Part II: Sea turtle fishery

1. What is the major threat to sea turtle survival in your region?

$\square$ Consumption/poaching $\square$ Bycatch $\square$ Habitat loss/contamination $\square$ Other

2. For those who put consumption/poaching as the most important threat, do you think that this threat is now less or more intense with respect to 10 years ago?

$\square$ More $\square$ Equal $\square$ Less $\square$ No opinion

3. How many people in your community eat sea turtle meat? 口 $0-25 \%$ ป $25-50 \%$ a $50-75 \%$ ป $75-100 \%$

4. How often do people eat sea turtle? $\square$ Never $\square$ <once a month $\square$ Once a month $\square$ Twice a month

$\square 3$ times a month $\square 4$ times a month $\square>4$ times a month $\square$ Occasionally

5. Do you know if there are illegal fishers working in the area?

6. Have you seen/heard of people hunting sea turtles in the area?

7. How many turtles are caught and how often?

8. Are sea turtles sold at the local market or are they only consumed within the family?

9. Do you know if sea turtle meat is exported to other towns? Which ones?

10. What are the prices for sea turtle meat at the beach? At the local market?

11 . Which are the main destinations of sea turtle products?

12. How are sea turtles caught?

13. When are sea turtles most often caught? On which occasions?

14. Do you have an idea of how many specimens are killed per week/month/season?

15. Do you know or have you heard about government authorities being involved in sea turtle traffic (anecdotal stories, examples)?
Editorial responsibility: Helene Marsh, Townsville, Queensland, Australia
Submitted: September 24, 2008; Accepted: October 20, 2008 Proofs received from author(s): February 15, 2009 